\title{
Cytotoxicity of Biologically Synthesized Silver Nanoparticles in MDA-MB-231 Human Breast Cancer Cells
}

\author{
Sangiliyandi Gurunathan, ${ }^{1}$ Jae Woong Han, ${ }^{1}$ Vasuki Eppakayala, ${ }^{1}$ \\ Muniyandi Jeyaraj, ${ }^{2}$ and Jin-Hoi Kim ${ }^{1}$ \\ ${ }^{1}$ Department of Animal Biotechnology, Konkuk University, 1 Hwayang-dong, Gwangjin-gu, Seoul 143-701, Republic of Korea \\ ${ }^{2}$ GS Centre for Life Sciences, Sundarapuram, Coimbatore, Tamil Nadu 641024, India
}

Correspondence should be addressed to Sangiliyandi Gurunathan; gsangiliyandi@yahoo.com

and Jin-Hoi Kim; jhkim541@konkuk.ac.kr

Received 4 January 2013; Revised 5 June 2013; Accepted 6 June 2013

Academic Editor: B. E. Kemp

Copyright ( 2013 Sangiliyandi Gurunathan et al. This is an open access article distributed under the Creative Commons Attribution License, which permits unrestricted use, distribution, and reproduction in any medium, provided the original work is properly cited.

\begin{abstract}
Silver nanoparticles (AgNPs) have been used as an antimicrobial and disinfectant agents. However, there is limited information about antitumor potential. Therefore, this study focused on determining cytotoxic effects of AgNPs on MDA-MB-231 breast cancer cells and its mechanism of cell death. Herein, we developed a green method for synthesis of AgNPs using culture supernatant of Bacillus funiculus, and synthesized AgNPs were characterized by various analytical techniques such as UV-visible spectrophotometer, particle size analyzer, and transmission electron microscopy (TEM). The toxicity was evaluated using cell viability, metabolic activity, and oxidative stress. MDA-MB-231 breast cancer cells were treated with various concentrations of AgNPs ( 5 to $25 \mu \mathrm{g} / \mathrm{mL}$ ) for $24 \mathrm{~h}$. We found that AgNPs inhibited the growth in a dose-dependent manner using MTT assay. AgNPs showed dose-dependent cytotoxicity against MDA-MB-231 cells through activation of the lactate dehydrogenase (LDH), caspase3 , reactive oxygen species (ROS) generation, eventually leading to induction of apoptosis which was further confirmed through resulting nuclear fragmentation. The present results showed that AgNPs might be a potential alternative agent for human breast cancer therapy.
\end{abstract}

\section{Introduction}

Breast cancer is the second most common cause of cancer death in women $[1,2]$. Many cancers initially respond to chemotherapy, and later they develop resistance [3-5]. Currently available chemopreventives and chemotherapeutic agents cause undesirable side effects [6,7]; therefore developing a biocompatible and cost effective method of treatment for cancer is indispensable. The development of nanotechnology has been a boon to mankind as its significance paved the way for several applications in therapeutics [8], catalysis [9], microelectronics, biosensing devices [10], air and water purifiers, paints [11], and so forth. Recently, AgNPs have gained much interest among the emerging nanoproducts in the field of nanomedicine due to their unique properties and obvious therapeutic potential in treating a variety of diseases, including retinal neovascularization [12-15]. The nanoparticles can be synthesized by physical, chemical, and biological methods. The physical methods are initially used to give a low yield [16]. Chemical methods use various chemical agents to reduce metallic ions to nanoparticles. This comprises certain drawbacks as there will be use of toxic chemicals and generation of hazardous byproducts [16]. In the medical aspects, applications of nanoparticles increased tremendously only when the biological approach for nanoparticle synthesis came into focus. The various resources available naturally for green synthesis of nanoparticles are plants, plant products, bacteria, fungi, algae, yeast, and viruses [17]. Though there is a large platform for the green synthesis of nanoparticles, the most commonly preferred way is the bacterial synthesis, as they are easy to handle, and genetic manipulation is also possible $[13,18,19]$. 
The major implication of this biological approach is simple and less time consuming. In addition to this the high yield, low toxicity, low cost, and its biocompatibility add to its value [20]. An additional advantage is that the size of the nanoparticles synthesized can also be easily controlled by various controlling parameters like $\mathrm{pH}$, temperature [13], and the use of stabilizers to prevent aggregation is not required as the proteins in the system act as stabilizers [14]. Nanoparticles with smaller radius of curvature have higher catalytic activity; hence angular shapes are preferable due to their smaller radii of curvature compared to spherical particles of the same volume. Several research groups have successfully demonstrated the superior antimicrobial efficacy of AgNPs either as they are or in composites with polymer [21-25]. In addition, our group and another research group demonstrated that AgNPs have potential cytotoxicity against cancer $[15,26,27]$ and antiangiogenic property in microvascular endothelial cells [28, 29].

Recently, Rani et al. [27] reported that AgNPs inhibit proliferation of human glioblastoma cells. Franco-Molina et al. [30] evaluated the effects of colloidal silver on MCF7 human breast cancer cells. Sanpui et al. [31] demonstrated that AgNPs, not only disrupting normal cellular function and but also affecting the membrane integrity, induced various apoptotic signaling genes of mammalian cells leading to programmed cell death. Hsin et al. [32] reported that AgNPs induced apoptosis in NIH3T3 cells by heightening the ROS generation and activated JNK pathway leading to mitochondria-dependent apoptosis. Recent studies have shown that AgNPs accumulation in the liver could induce cytotoxicity via oxidative cell damage [32-34]. Reactive oxygen species (ROS) are continually generated and eliminated in biological systems. They play an important role in a variety of normal biochemical functions, and abnormality in their function results in pathological processes. Excessive production of ROS in the cell is known to induce apoptosis $[35,36]$. ROS generation has been shown to play an important role in apoptosis induced by treatment with AgNPs [27, 37, 38].

A number of studies have reported that AgNPs may induce cytotoxicity in phagocytosing cells, such as not only mouse peritoneal macrophages but also human monocytes [38-40]. Further studies suggested that the cytotoxic effects were induced by reactive oxygen species (ROS) resulting in cellular apoptosis, at least low concentrations and short incubation times [37, 41-43]. The production of ROS has also been implicated in DNA damage caused by AgNPs, which was reported in a number of in vitro studies [27, $38,44]$. Caspase-3 is one of the key molecules in apoptosis, and its activation is often considered as the point of no return in apoptosis [45]. Activation of caspase-3 results in the cleavage of (inhibitor of caspase-activated DNAse) ICAD and translocation of (caspase activated DNAse) CAD to the nucleus, ultimately resulting in DNA fragmentation. The most prominent event in the early stages of apoptosis is internucleosomal DNA cleavage by endonuclease activities [46]. Previous studies suggested that AgNPs treated cancer cell, and noncancer cells revealed enhanced caspase- 3 activity and formation of significant DNA laddering [14, 15, 47].
Currently, a variety of cytotoxic agents have been used in the treatment of breast cancer, such as doxorubicin, cisplatin, and bleomycin [30, 48]. Although usage of doxorubicin, cisplatin, and bleomycin provides beneficial effect, but the efficacy and demerits are uncertain [30]. Therefore, it is necessary to find novel therapeutic agents against cancer, which are biocompatible and cost effective. Therefore, this study was designed to synthesize AgNPs using biological system and to evaluate potential toxicity and the general mechanism of biologically synthesized AgNPs in MDA-MB231 human breast cancer cells.

\section{Materials and Methods}

2.1. Materials. Penicillin-streptomycin solution, trypsin-EDTA solution, RPMI-1640 medium, Dulbecco's modified Eagle's medium (DMEM/F-12), and 1\% antibiotic-antimycotic solution were obtained from Life Technologies GIBCO, Grand Island, NY, USA. Fetal bovine serum (FBS), in vitro toxicology assay kit, was purchased from Sigma-Aldrich (St. Louis, MO, USA).

2.2. Synthesis of AgNPs. Luria-Bertani broths were prepared and used as described earlier [13]. B. funiculus cultures were obtained from the GS Center for Life Sciences, Coimbatore, India. The novel bacteria were isolated from industrial wastewater, and sequence has been submitted at GenBank. The strain was grown aerobically at $37^{\circ} \mathrm{C}$ in $\mathrm{LB}$ medium. Synthesis of AgNPs was carried out according to the method described previously [13]. Briefly, bacteria were grown in a $500 \mathrm{~mL}$ Erlenmeyer flask that contained LB broth without $\mathrm{NaCl}$ or nitrate medium. The flasks were incubated for $21 \mathrm{~h}$ in a shaker set at $120 \mathrm{rpm}$ and $37^{\circ} \mathrm{C}$. After the incubation period, the culture was centrifuged at $10,000 \mathrm{rpm} / \mathrm{min}$ and the supernatant used for the synthesis of AgNPs. Three vials the first containing $\mathrm{AgNO}_{3}$ (Sigma, USA, 99.9\% pure) without the supernatant, the second containing only the culture supernatant, and the third containing the supernatant and $\mathrm{AgNO}_{3}$ solution at a concentration of $1 \mathrm{mM}$ were incubated for $60 \mathrm{~min}$ at $40^{\circ} \mathrm{C}$. The extracellular synthesis of AgNPs was monitored by visual inspection of the test tubes for a change in the color of the culture medium from a clear, light yellow to brown, and by measurement of the peak exhibited by AgNPs in the UV-vis spectra the synthesis of nanoparticles was confirmed.

2.3. Cell Culture. MDA-MB-231 human breast cancer cells were kindly provided by Professor Ssang-Goo, Department of Animal Biotechnology, Konkuk University, and were maintained in Dulbecco's modified Eagle's medium (DMEM) supplemented with $10 \%$ fetal bovine serum (FBS) and $1 \%$ antibiotic-antimycotic solution. Cells were grown to confluence at $37^{\circ} \mathrm{C}$ and $5 \% \mathrm{CO}_{2}$ atmosphere. All experiments were performed in 6-well plates, unless stated otherwise. Cells were seeded onto the plates at a density of $1 \times 10^{6}$ cells per well and incubated for $24 \mathrm{~h}$ prior to the experiments. The cells were washed with (phosphate buffered saline, $\mathrm{pH} 7.4$ ) 
PBS and incubated in fresh medium containing different concentrations of AgNPs dissolved in water.

2.4. Characterization of AgNPs. Characterization of synthesized AgNPs particles was carried out according to the methods described previously $[13,49]$. The AgNPs were primarily characterized by UV-visible spectroscopy. Ultravioletvisible (UV-vis) spectra were obtained using a WPA (Biowave II), Biochrom, Cambridge, UK. The particle size of dispersions was measured by Zetasizer Nano ZS90 (Malvern Instruments, Ltd., UK). Transmission electron microscopy (TEM, JEM-1200EX) was used to determine the size and morphology of AgNP.

2.5. Cell Viability Assay. The cell viability assay was measured using the 3-(4,5-dimethylthiazol-2-yl)-2,5-diphenyltetrazolium bromide dye reduction assay which was performed to determine the cytotoxic effect of the AgNPs at various concentrations. Briefly, the MDA-MB-231 cells were plated onto 96-well flat bottom culture plates with various concentrations of AgNPs. All cultures were incubated for $24 \mathrm{~h}$ at $37^{\circ} \mathrm{C}$ in a humidified incubator. After $24 \mathrm{~h}$ of incubation $\left(37^{\circ} \mathrm{C}, 5 \% \mathrm{CO}_{2}\right.$ in a humid atmosphere), $10 \mu \mathrm{L}$ of MTT ( $5 \mathrm{mg} / \mathrm{mL}$ in PBS) was added to each well, and the plate was incubated for a further $4 \mathrm{~h}$ at $37^{\circ} \mathrm{C}$. The resulting formazan was dissolved in $100 \mu \mathrm{L}$ of DMSO with gentle shaking at $37^{\circ} \mathrm{C}$, and absorbance was measured at $595 \mathrm{~nm}$ with an ELISA reader (Spectra MAX; Molecular Devices, USA). The results were given as the mean of three independent experiments. Concentrations of AgNPs showing a 50\% reduction in cell viability (i.e., IC50 values) were then calculated.

2.6. Membrane Integrity. Cell membrane integrity of MDAMB-231 cells was evaluated by determining the activity of lactate dehydrogenase (LDH) leaking out of the cell according to the manufacturer's instructions (in vitro toxicology assay kit, TOX7, Sigma, USA). The LDH assay is based on the release of the cytosolic enzyme, $\mathrm{LDH}$, from cells with damaged cellular membranes. Thus, in cell culture, the course of AgNPs induced cytotoxicity was followed quantitatively by measuring the activity of LDH in the supernatant. Briefly, cells were exposed to various concentrations of AgNPs for $24 \mathrm{~h}$, then $100 \mu \mathrm{L}$ per well of each cell-free supernatant was transferred in triplicates into wells in a 96-well, and $100 \mu \mathrm{L}$ of $\mathrm{LDH}$ assay reaction mixture was added to each well. After 3-hour incubation under standard conditions, the optical density of the color generated was determined at a wavelength of $490 \mathrm{~nm}$ using a Microplate Reader.

2.7. Determination of ROS. Intracellular reactive oxygen species (ROS) were measured based on the intracellular peroxide-dependent oxidation of $2^{\prime}, 7^{\prime}$-dichlorodihydrofluorescein diacetate (DCFH-DA, Molecular Probes, USA) to form the fluorescent compound $2^{\prime}, 7^{\prime}$-dichlorofluorescein (DCF), as previously described [50]. Cells were seeded onto 24-well plates at a density of $5 \times 10^{4}$ cells per well and cultured for $24 \mathrm{~h}$. After washing twice with PBS, fresh medium containing $8.7 \mu \mathrm{g}$ AgNPs or $1 \mathrm{mM} \mathrm{H}_{2} \mathrm{O}_{2}$ was added, and the cells were incubated for $24 \mathrm{~h}$. For control, the cells were added $20 \mu \mathrm{M}$ of DCFH-DA, and incubation continued for $30 \mathrm{~min}$ at $37^{\circ} \mathrm{C}$. The cells were rinsed with PBS, $2 \mathrm{~mL}$ of PBS was added to each well, and fluorescence intensity was determined with spectrofluorometer (Gemini EM) with excitation at 485 and emission at $530 \mathrm{~nm}$. For control, the cells grown in 24-well plates for $24 \mathrm{~h}$ were added an antioxidant $\mathrm{N}$ acetyl-L-cystein (NAC, $5 \mathrm{mM}$ ) for $1 \mathrm{~h}$ prior to exposing them to 17.4 to $8.7 \mu \mathrm{g} / \mathrm{mL}$ AgNPs or $1 \mathrm{mM} \mathrm{H}_{2} \mathrm{O}_{2}$ for $12 \mathrm{~h} .20 \mu \mathrm{M}$ of DCFH-DA was then added, and the cells were incubated for $30 \mathrm{~min}$ at $37^{\circ}$ before measuring changes of DCF fluorescence as described.

2.8. Measurement of Caspase-3 Activity. The cells were treated with $8.7 \mu \mathrm{g}$ AgNPs or purified caspase-3 or inhibitor for $24 \mathrm{~h}$. The activity of caspase- 3 was measured in MDA-MB-231 cells using a kit from Sigma (St. Louis, MO, USA) according to the manufacturer's instructions. Cells were washed with icecold PBS and lysed with $100 \mu \mathrm{L}$ of lysis buffer [50 mM Tris$\mathrm{HCl}$ (pH 7.5), $150 \mathrm{mM} \mathrm{NaCl}, 1 \mathrm{mM}$ EGTA, $1 \mathrm{mM} \mathrm{NaF}, 1 \%$ Nonidet P-40, $1 \mathrm{mM}$ PMSF, and protease inhibitor cocktail] for $30 \mathrm{~min}$ at $4^{\circ} \mathrm{C}$. Protein extracts were collected after centrifugation at $14,000 \mathrm{rpm}$ for $10 \mathrm{~min}$. Protein concentration was determined using the Bio-Rad protein assay kit (Bio-Rad, USA). Equal amounts $(50 \mu \mathrm{g})$ of protein extracts were mixed with assay buffer [20 mM HEPES ( $\mathrm{pH} 7.4$ ), $100 \mathrm{mM} \mathrm{NaCl}$, 0.1\% CHAPS, $10 \mathrm{mM}$ DTT, $1 \mathrm{mM}$ EDTA, and $10 \%$ sucrose], added to 96-well Microtiter plates, and incubated with the caspase-3 substrate (acetyl-Asp-Glu-Val-Asp p-nitroanilide (Ac-DEVD-pNA) and caspase-3 inhibitor (Ac-DEVD-CHO) for $1 \mathrm{~h}$ and the absorbance read at $405 \mathrm{~nm}$. The colorimetric assay is based on the hydrolysis of caspase- 3 substrate by caspase-3, resulting in the release of the p-nitroaniline (pNA) moiety. The concentration of the pNA released from the substrate is calculated from the absorbance values at $405 \mathrm{~nm}$. The assay was done with noninduced cells and also in the presence of purified caspase- 3 and caspase- 3 inhibitor (AcDEVD-CHO) for a comparative analysis.

2.9. DNA Fragmentation Assay. MDA-MB- 231 ( $10^{6}$ cells $\left.\mathrm{mL}\right)$ were seeded in 6-well Microplates and treated with $8.7 \mu \mathrm{g} / \mathrm{mL}$ of AgNPs. After $24 \mathrm{~h}$ of treatment, the culture medium was removed, and the cells were harvested by scraping with $1 \mathrm{~mL}$ of PBS and lysed with $500 \mu \mathrm{L}$ of lysis buffer [ $20 \mathrm{mM}$ Tris$\mathrm{HCl}$ (pH 8.0), $5 \mathrm{mM}$ EDTA, $400 \mathrm{mM} \mathrm{NaCl}, 1 \%$ SDS, and $10 \mathrm{mg} / \mathrm{mL}$ proteinase $\mathrm{K}]$ for $1 \mathrm{~h}$ at $55^{\circ} \mathrm{C}$. Fragmented DNA was extracted with phenol/chloroform/isoamyl alcohol (25:24:1 $\mathrm{v} / \mathrm{v} / \mathrm{v}$ ), precipitated with ethanol, and resuspended in TrisEDTA buffer (TE, pH 8.0) containing $20 \mu \mathrm{g} / \mathrm{mL}$ RNase A. For quantitative analyses of DNA content, an equal amount of DNA was loaded and run on a 1.0\% agarose gel containing $1 \mu \mathrm{g} / \mathrm{mL}$ ethidium bromide at $70 \mathrm{~V}$, and the DNA fragments were visualized by exposing the gel to ultraviolet light, followed by photography. For control, cells grown in 24well plates for $24 \mathrm{~h}$ were added an antioxidant $\mathrm{N}$-acetyl-Lcystein (NAC, $5 \mathrm{mM}$ ) for $1 \mathrm{~h}$ prior to exposing them to $8.7 \mu \mathrm{M}$ AgNPs. 


\section{Results and Discussion}

3.1. Extracellular Synthesis of AgNPs. There are several physical and chemical methods that have been used for the synthesis of metallic nanoparticles [51]. The development of biological method is essential because it provides cost effective, environmentally friendly, and easy process for synthesis and application of metallic nanoparticles. Several microorganisms have the potential to interact with metal ions reducing them into metallic nanoparticles [52]. In this work, we took the advantage of using microorganism for synthesis of AgNPs using the culture supernatants of B. funiculus. As shown in Figure 1, the supernatants of $B$. funiculus were incubated with silver nitrate $(1 \mathrm{mM})$. The appearance of a yellowish-brown color in the reaction vessels suggested the formation of colloidal AgNPs. Thus, it was evident that the metabolites excreted by the culture exposed to silver could reduce silver ions, clearly indicating that the reduction of the ions occurs extracellularly through reducing agents released into the solution by B. funiculus. The color change from yellow to brown provides a piece of evidence to support the synthesis of AgNPs, and also it is due to the excitation of surface plasmon vibrations, typical of AgNPs [13, 53-56].

Further, the AgNPs were characterized by UV-visible spectroscopy. The UV-visible absorption spectra of the cell filtrates were measured in the range of $300-700 \mathrm{~nm}$ using a UV-visible spectrophotometer. This technique has been proved to be a very valuable and useful technique for the characterization of nanoparticles [53-55]. By using UVvisible spectroscopy, we could measure the diameter by the spectral response of silver nanoparticles; as the diameter increases, the peak plasmon resonance shifts to longer wavelengths and broadens. Additionally, UV-visible spectroscopy provides a mechanism to monitor how the nanoparticles change over time. A strong and broad surface plasmon peak located at $420 \mathrm{~nm}$ was observed for the AgNPs prepared using supernatants of B. funiculus (Figure 2). The band around $420 \mathrm{~nm}$ suggests that the particles were well dispersed without aggregation. Observation of the strong but broad surface plasmon peak has been well known in the case of various metal nanoparticles over a wide size range of 2$100 \mathrm{~nm}[53,54]$.

3.2. Size Distribution Analysis by Dynamic Light Scattering (DLS). To know the size of synthesized AgNPs, size distribution analysis was performed using dynamic light scattering in aqueous solution. It was found that the average size of AgNPs was $20 \mathrm{~nm}$. Figure 3 shows that the particles range in size from 10 to $20 \mathrm{~nm}$ and possess an average size of $20 \mathrm{~nm}$ synthesized by $B$. funiculus. DLS results showed an average diameter of $20 \mathrm{~nm}$ and a low polydispersity index of less than 0.08 indicating that a monodisperse distribution of mostly a single and uniform size of species is present in solution.

Regarding the size of the AgNPs, several studies have been reported using a biological system such as using culture supernatant of $K$. pneumonia produces the size of particles range from 28.2 to $122 \mathrm{~nm}$ and possess an average size of $52.5 \mathrm{~nm}$ [55]. Similarly, both culture supernatant and biomass of $B$. licheniformis producesabout the size of $50 \mathrm{~nm}[49,56]$.
Gurunathan et al. [13] reported that the particles range in size from 42.2 to $89.6 \mathrm{~nm}$ and possess an average size of $50 \mathrm{~nm}$ size of AgNP synthesized from culture supernatant of E. coli was $50 \mathrm{~nm}$; using DLS and TEM. Shanshoury et al. [57] reported the extracellular biosynthesis of metallic AgNPs by the reduction of aqueous $\mathrm{Ag}^{+}$using Escherichia coli ATCC 8739, Bacillus subtilis ATCC 6633, and Streptococcus thermophilus ESh1 and revealed the size range between 5 and $25 \mathrm{~nm}$.

3.3. Size and Morphology Analysis of AgNPs by Transmission Electron Microscopy (TEM). Further characterization of AgNPs was examined using TEM to know the size and morphology of AgNPs; the representative TEM image was shown in Figure 4 and indicates well-dispersed particles which are more or less spherical. The TEM analysis revealed that the particle size of silver particles shows that the particle size ranges from 10 to $20 \mathrm{~nm}$.

To determine their size distribution, we measured approximately more than 200 particles from various samples and represented them as the size distribution analysis (Figure 4(b)). The average size of the particles synthesized by B. funiculus is approximately $20 \mathrm{~nm}$. A significant proportion of largely spherical AgNPs within the range of $20 \mathrm{~nm}$ were observed in TEM micrographs. The spherical particles are reasonably uniform and range in size from 10 to $20 \mathrm{~nm}$ and are in agreement with DLS data.

3.4. Dose-Dependent Cytotoxicity Effect of AgNPs in MDAMB-231 Cells. The cell viability assay is one of the important methods for toxicology analysis which explain the cellular response to a toxic materials, and it can provide information on cell death, survival, and metabolic activities [27]. Recently, Piao et al. [43] reported that AgNPs and $\mathrm{AgNO}_{3}$ showed cytotoxicity in a dose-dependent manner in human Chang liver cells; among these materials AgNPs showed higher cytotoxicity compared to $\mathrm{AgNO}_{3}$. AgNPs treated cells showed the decreased metabolic activity, which depends on nature of cell types and size of nanoparticles [58]. Franco-Molina et al. [30] reported that colloidal silver induced dose-dependent cytotoxic effect on MDA-MB-231 breast cancer cells. In our experiment, the cells were treated with various concentrations $(0-25 \mu \mathrm{g} / \mathrm{mL})$ of AgNPs for $24 \mathrm{~h}$, and the results suggest that AgNPs were able to reduce the cell viability of MDA-MB231 cells in a dose dependent manner. At $24 \mathrm{~h}$ of treatment, AgNPs was found to be cytotoxic to the cells at concentrations of $10 \mu \mathrm{g} / \mathrm{mL}$ and higher (Figure 5). In agreement with our results, other research groups have reported that cell viability was significantly reduced as a function of both culture time and AgNP concentration in human IMR-90 and U251 cells, mouse embryonic stem cells, and A549 lung cells [27, 44]. Our results suggest that the lowest concentration of AgNPs significantly inhibits the growth of cells.

3.5. Impact of AgNPs on Membrane Integrity. $\mathrm{LDH}$ is a soluble cytosolic enzyme, which is released into the extracellular medium because membrane damage consequently leads to apoptosis. It is widely accepted as an indicator of lytic cell 


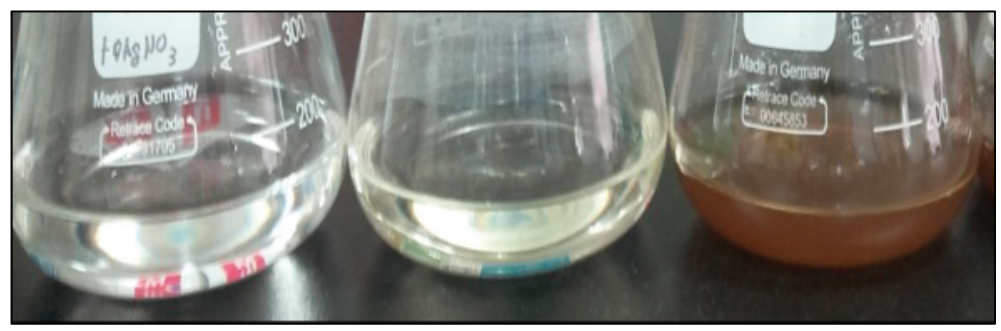

(a)

(b)

(c)

Figure 1: Synthesis of AgNPs by culture supernatant of $B$. funiculus. The figure shows flask containing samples of $\mathrm{AgNO}_{3}$ after exposure to $60 \mathrm{~min}$ (a), $\mathrm{AgNO}_{3}$ with the extracellular culture supernatant of B. funiculus (b), and $\mathrm{AgNO}_{3}$ plus supernatant of $B$. funiculus (c). It is observed that the color of the solution turned from colorless to brown after $1 \mathrm{~h}$ of the reaction, indicating the formation of AgNPs.

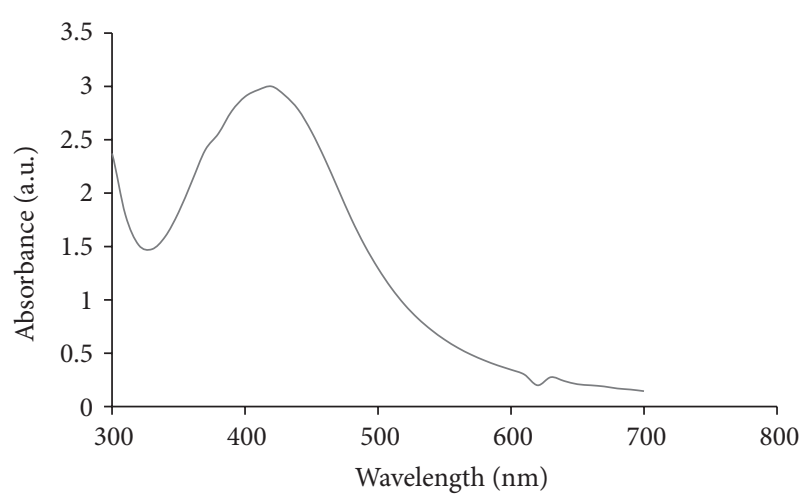

FIgURe 2: The absorption spectrum of AgNPs synthesized by $B$. funiculus culture supernatant. The absorption spectrum of AgNPs exhibited a strong broad peak at $420 \mathrm{~nm}$, and observation of such a band is assigned to surface plasmon resonance of the particles. The samples were collected and were incubated with $1 \mathrm{mM}$ silver nitrate solution. After the incubation period, the samples were visualized in UV-vis spectra.

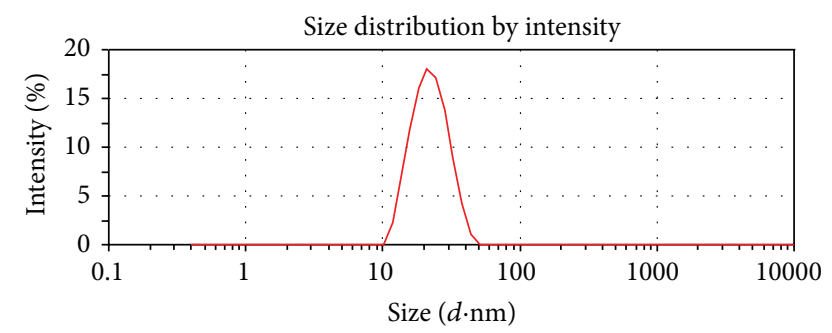

Figure 3: Size distribution analysis by DLS. The particle size distribution revealed that the particles range from $10-20 \mathrm{~nm}$. The average particle size was found to be $20 \mathrm{~nm}$.

death. The results show that cell membrane integrity in MDAMB-231 cells was compromised in a dose dependent manner by AgNPs of $20 \mathrm{~nm}$ diameter (Figure 6). The inverse relationship between the LDH and the MTT cell viability results adds support to the accuracy of the data. In the LDH assay, as the concentration of the AgNPs increased, cells became progressively more cytotoxic, leading to a higher absorbance reading in the LDH assay and a decrease in absorbance in the MTT assay with a concurrent decrease in the percentage of viable cells. Park et al. [58] observed with various sizes of AgNPs that cell membrane integrity in L929 fibroblasts was compromised by all three AgNPs, with $20 \mathrm{~nm}$ AgNPs being more potent than 80 and $113 \mathrm{~nm}$ AgNPs. However the cell membrane integrity was affected slightly in RAW 264.7 macrophages. Song et al. [59] reported that water-soluble mPEG-SH-coated AgNPs decreased cell viability in doseand time-dependent manners at dosage levels between 6.25 and $100.00 \mu \mathrm{g} / \mathrm{mL}$, caused membrane damage (LDH leakage), and decreased the activities of superoxide dismutase and glutathione peroxides. AgNPs induced the release of $\mathrm{LDH}$ in a concentration- and time-dependent manner, indicating that AgNPs reduced the membrane potential in A549 cells. Lee et al. [60] observed that the LDH level was increased $210 \%$ when cells were cultivated for $48 \mathrm{~h}$ in the culture medium containing AgNPs at $100 \mu \mathrm{g} / \mathrm{mL}$. Hussain et al. [33] demonstrated that exposure to AgNPs for $24 \mathrm{~h}$ resulted in a concentration-dependent increase in $\mathrm{LDH}$ leakage and exhibited a significant cytotoxicity at $10-50 \mu \mathrm{g} / \mathrm{mL}$ in BRL 3A rat liver cells.

3.6. Determination of IC50 Values of AgNPs. To focus on the cytotoxic effect of particular concentration, the half maximal inhibitory concentration (IC50) was calculated as the concentration required to inhibit the growth of tumor cells in culture by $50 \%$ compared to the untreated cells. AgNPs at $8.7 \mu \mathrm{g} / \mathrm{mL}$ decreased the viability of MDA-MB-231 cells to $50 \%$, and this was chosen as the IC50. Longer exposures resulted in additional toxicity to the cells. These results demonstrate that AgNPs mediate a concentration-dependent increase in toxicity. Because $8.7 \mu \mathrm{g} / \mathrm{mL}$ concentrations of AgNPs were found to be the IC50, further experiments were carried out using this concentration, to show the effect of AgNPs against MDA-MB-231 cells. Gopinath et al. [26] investigated the molecular mechanism of $10-15 \mathrm{~nm}$ size of AgNP mediated cytotoxicity in BHK21 (noncancer) and HT29 (cancer) cells, and they observed that $27 \mu \mathrm{g} / \mathrm{mL}$ seems to be IC50. Zanette et al. [61] investigated the effects of AgNPs on skin using the human-derived keratinocyte $\mathrm{HaCaT}$ cell line model and suggested that AgNPs caused a concentration- and timedependent decrease of cell viability, with IC50 values of 6.8 \pm 1 . $\mu \mathrm{M}$ (MTT assay) and $12 \pm 1.2 \mu \mathrm{M}$ (SRB assay) after 7 days of contact. The IC50 results obtained from our studies 


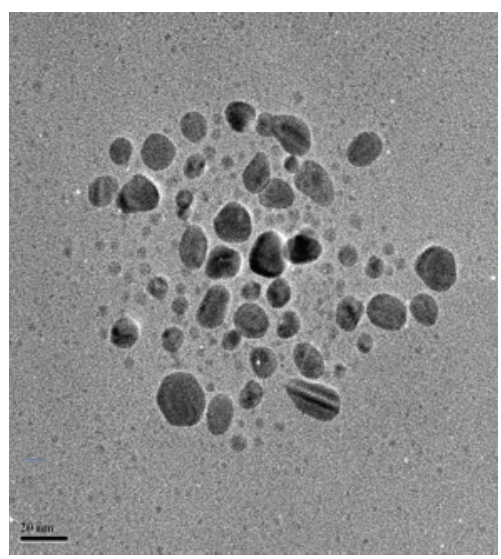

(a)

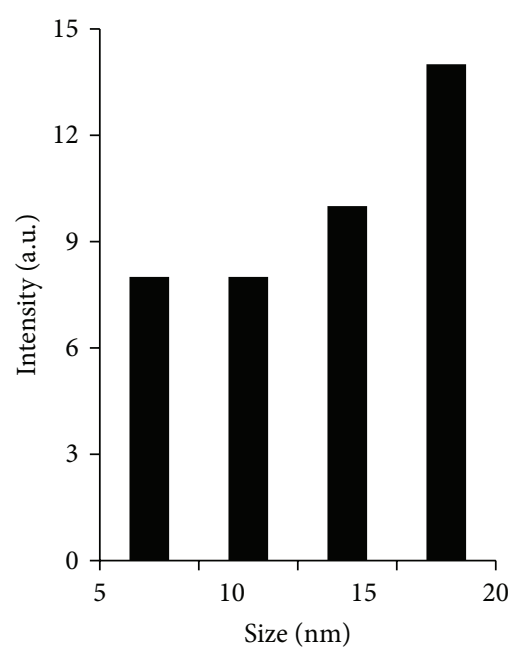

(b)

FIGURE 4: Size and morphology of AgNPs analysis by TEM. (a) Several fields were photographed and were used to determine the diameter of nanoparticles. The average range of observed diameter was $20 \mathrm{~nm}$. (b) Particle size distributions from TEM image.

are comparable with earlier reports, and synthesized AgNPs show more efficacy than earlier reports. However, the action of AgNP depends on size, shape, conditions of media, and type of cells are and also dose and time dependent.

3.7. Effect of AgNPs in Cellular Reactive Oxygen Species. Oxidative stress is one of the key mechanisms of toxicity related to nanoparticle exposure [62]. The interaction between AgNPs and mammalian cells can induce oxidative stress by inducing the cellular ROS production so that it exceeds the cellular antioxidant capacity [27]. Oxidative stress plays important roles in a variety of normal biochemical functions, and abnormality in their function results in pathological processes. Excessive production of ROS in the cell is known to induce apoptosis $[63,64]$. ROS generation has been shown to play an important role in apoptosis induced by treatment with AgNPs [27, 37, 38]. Our studies provided evidence for a molecular mechanism of AgNPs inducing generation of ROS, and it could be one of the factors for apoptosis. Earlier studies show that AgNPs could induce generation of ROS in macrophages [58] and human Chang liver cells [43].

To know the effect of AgNPs in oxidative stress, we measured ROS generation using the H2DCF-DA assay. AgNPs induced intracellular ROS generation was evaluated using intracellular peroxide-dependent oxidation of DCFHDA to form fluorescent DCF. Cells were also treated with a characteristic ROS generating agent, $\mathrm{H}_{2} \mathrm{O}_{2}(1 \mathrm{mM})$, as a positive control. DCF fluorescence was detected in cells treated with AgNPs for $24 \mathrm{~h}$. As shown in Figure 7, the ROS levels generated in response to AgNPs were significantly higher in AgNPs treated cells than control. ROS generation in cells treated with both AgNPs and $\mathrm{H}_{2} \mathrm{O}_{2}$ was decreased when the cells were pretreated with NAC, an antioxidant. Taken together, all these results indicate that cell death is mediated

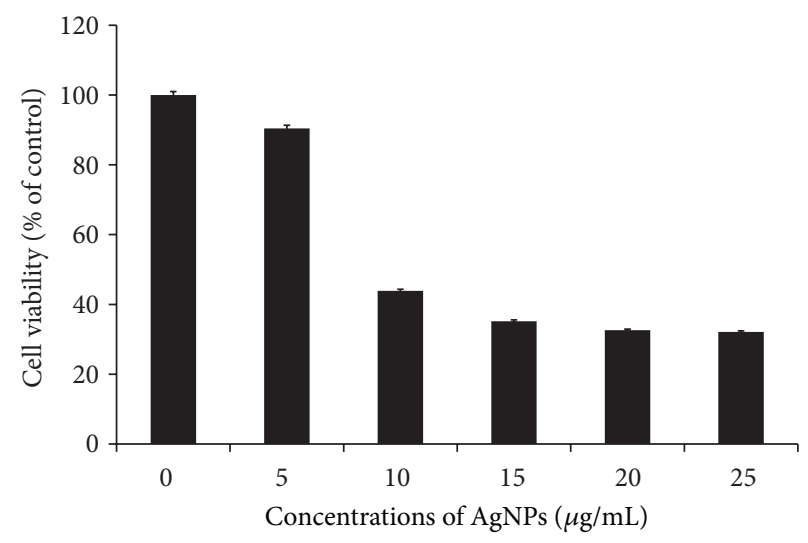

FIgURE 5: Effect of AgNPs on Cell viability of MDA-MB-231 cells. Cells were treated with AgNPs at various concentrations for $24 \mathrm{~h}$, and cytotoxicity was determined by the MTT method. The results represent the means of three separate experiments, and error bars represent the standard error of the mean. Treated groups showed statistically significant differences from the control group by the Student's $t$-test $(P<0.05)$.

by ROS production, which might alter the cellular redox status, and it is a potential reason for cell death.

3.8. Caspase-3 Activation of AgNP-Induced Apoptosis. The caspase-3 activation cascade plays an important role in several apoptotic mechanisms [65-67]. To investigate the potential effect of AgNP on apoptotic pathway, we examined the activity of caspase- 3 in AgNP treated MDA-MB-231 cells. Figure 8 depicts the increase in the levels of caspase- 3 during treatment with AgNPs. The IC 50 value of AgNPs $8.7 \mu \mathrm{g} / \mathrm{mL}$ increased the activity of caspase- 3 to a level comparable with that of caspase- 3 activation. The cellular metabolic activity seems to be affected by the AgNPs therefore, the possibility 


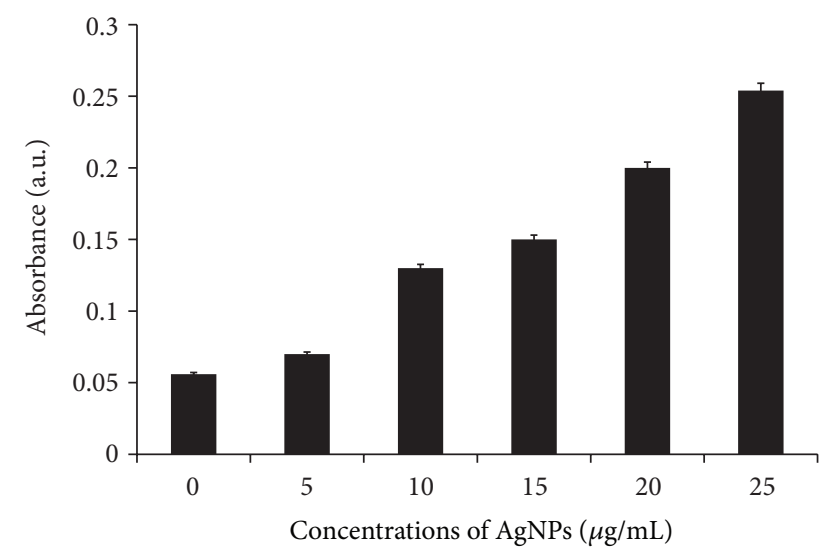

Figure 6: Effect of AgNPs on LDH activity in MDA-MB-231. LDH activity was measured by changes in optical densities due to $\mathrm{NAD}^{+}$reduction which were monitored at $490 \mathrm{~nm}$, as described in Materials and Methods Section, using the cytotoxicity detection lactate dehydrogenase kit. The results represent the means of three separate experiments, and error bars represent the standard error of the mean. Treated groups showed statistically significant differences from the control group by the Student's $t$-test $(P<0.05)$.

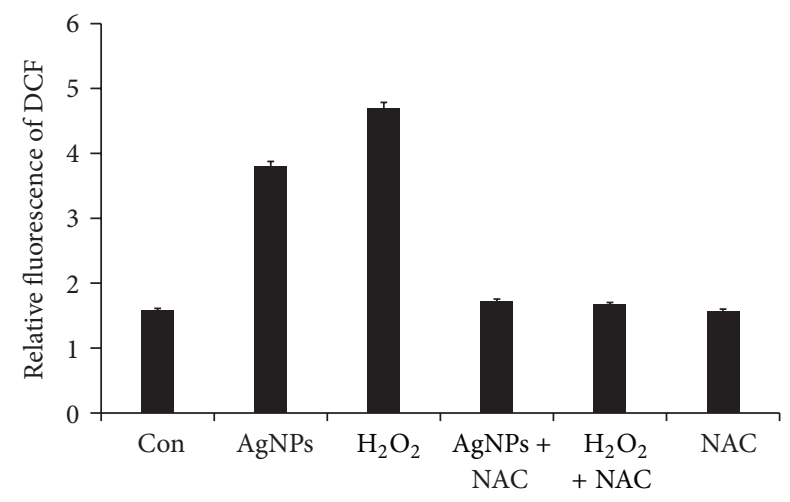

FIgURE 7: ROS generation in AgNPs treated MDA-MB-231 cells. Relative fluorescence of DCF was measured using a spectrofluorometer with excitation at 485 and emission at $530 \mathrm{~nm}$. The results represent the means of three separate experiments, and error bars represent the standard error of the mean. Treated groups showed statistically significant differences from the control group by the Student's $t$-test $(P<0.05)$.

of apoptosis induction by the AgNPs was assessed, especially at the IC50. Levels of caspase-3, a molecule which plays a key role in the apoptotic pathway of cells, were increased following the treatment with AgNPs. The increased level of caspase 3 activation suggested that AgNPs caused cell death through apoptosis.

3.9. DNA Fragmentation. The DNA laddering technique is used to visualize the endonuclease cleavage products of apoptosis [46]. This assay involves extraction of DNA from a lysed cell homogenate followed by agarose gel electrophoresis. Apoptosis of the AgNP treated cells was accompanied by a reduction in the percentage of cells in G0/G1 phase and an

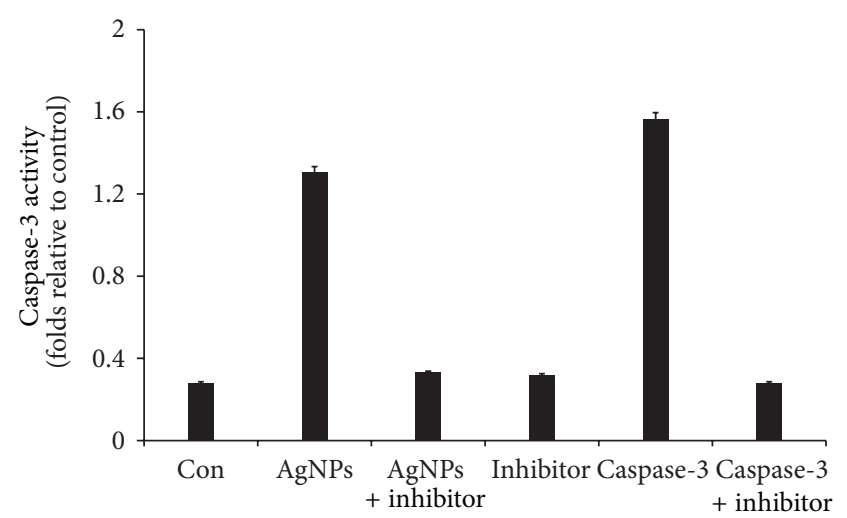

FIgURe 8: AgNPs induce apoptosis in MDA-MB-231 cells by caspase- 3 activation. MDA-MB-231 cells were treated with AgNPs, purified caspase-3, and caspase- 3 inhibitor for $24 \mathrm{~h}$. The assay was performed as described in Materials and Methods Section. The caspase- 3 activity is based on the hydrolysis of caspase- 3 substrate (acetyl-Asp-Glu-Val-Asp p-nitroanilide (Ac-DEVD-pNA) by caspase-3, resulting in the release of the p-nitroaniline (pNA) moiety. The concentration of the pNA released from the substrate is calculated from the absorbance values at $405 \mathrm{~nm}$. The assay was carried out in the presence of purified caspase- 3 and caspase- 3 inhibitor (Ac-DEVD-CHO) for a comparative analysis. The results represent the means of three separate experiments, and error bars represent the standard error of the mean. Treated groups showed statistically significant differences from the control group by the Student's $t$-test $(P<0.05)$.

increase in the percentage of $\mathrm{G} 2 / \mathrm{M}$ phase cells, indicating cell cycle arrest at G2/M [60]. The ROS can act as signal molecules promoting cell cycle progression and can induce oxidative DNA damage $[68,69]$. Further we examined the impact of AgNPs in DNA fragmentation. DNA fragmentation is broadly considered as a characteristic feature of apoptosis [70]. Induction of apoptosis can be confirmed by two factors such as irregular reduction in size of cells, in which the cells are reduced and shrunken, and lastly DNA fragmentation. The DNA fragmentation in the present study was verified by extracting DNA from MDA-MB-231 cells treated with various concentrations of AgNPs followed by detection in the agarose gel. Figure 9 clearly indicates that the DNA "laddering" pattern in MDA-MB-231 cells treated with AgNPs is one of the reasons for cell death. Earlier studies by Gurunathan and coworkers demonstrated that both cancer and noncancer cell lines treated with silver nanoparticle exhibit the formation of DNA ladder [14, 29]. The deposition of metal particles inside the nucleus could affect the DNA and cell division. Genotoxic studies of titanium dioxide $\left(\mathrm{TiO}_{2}\right)$ nanoparticles revealed dose-dependent DNA damage, chromosomal aberrations and errors in chromosome segregation [71], and formation of sister chromatic exchanges [72]. Treatment with AgNPs induced the production of micronuclei (MN) [27]. Mroz et al. [73] hypothesized that nanoparticles and reactive oxidative species induce DNA damage, activating p53 and proteins related to DNA repair, and mimicking irradiation related carcinogenesis. 


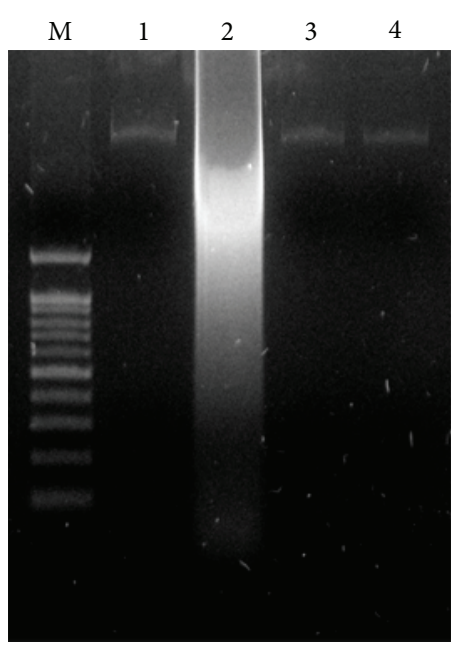

Figure 9: Effect of AgNPs on DNA fragmentation. MDA-MB-231 Cells were treated with AgNPs for $24 \mathrm{~h}$ and DNA fragmentation was analyzed by agarose gel electrophoresis. Lane $\mathrm{M}, 1 \mathrm{kB}$ ladder; lane 1, control; lane 2, AgNP $(8.7 \mu \mathrm{g} / \mathrm{mL})$; lane 3, AgNP + NAC; lane 4, $\mathrm{NAC}(5 \mathrm{mM})$.

\section{Conclusion}

Recently AgNPs are used as an antimicrobial agent in wound dressings and coatings in medical devices. Developing biocompatible molecule as an anticancer agent is one of the novel approaches in the field of cancer therapy using nanotechnology. We have successfully synthesized and prepared stable AgNPs (20 nm) using novel bacterium, B. funiculus, which is green, environmentally friendly, cost effective, and rapid method for synthesis of AgNPs. The present study revealed that the potential cytotoxic effect of biologically synthesized AgNP in MDA-MB-231 cells by inhibiting growth of cells concentration-dependent activation of LDH increased level of ROS generation and activation of caspase-3, which is considered to be the most significant of the executioner caspases resulting in cellular apoptosis. Our results suggest that oxidative stress seems to be involved in nanoparticle cytotoxicity. The overall results indicated that the biologically synthesized AgNPs have antiproliferative activity through induction of apoptosis in MDA-MB-231 breast cancer cell line, suggesting that biologically synthesized AgNPs might be a potential alternative agent for human breast cancer therapy. This study demonstrates the possibility of using AgNPs to inhibit the growth of the tumor cells and their cytotoxicity for potential therapeutic treatments and offers a new method to develop molecule for cancer therapy. Finally, cost effectiveness, biocompatibility, and facileness to modify these silver nanoparticles make them a viable choice in future biomedical applications.

\section{Acknowledgments}

This paper was supported by the SMART Research Professor Program of Konkuk University. Dr. Sangiliyandi Gurunathan was supported by Konkuk University SMART Full-time
Professorship. This work was supported by BioGreen 21 Program of the RDA (Grant no. PJ009625) and ARPC (Grant no. 111047-5), Republic of Korea.

\section{References}

[1] K. Chan and G. J. Morris, "Chemoprevention of breast cancer for women at high risk," Seminars in Oncology, vol. 33, no. 6, pp. 642-646, 2006.

[2] A. Jenal, A. Thomas, and T. Murry, "Cancer stastics," CA: A Cancer Journal for Clinicians, vol. 52, pp. 23-37, 2002.

[3] S. R. D. Johnston, "Acquired tamoxifen resistance in human breast cancer-potential mechanisms and clinical implications," Anti-Cancer Drugs, vol. 8, no. 10, pp. 911-930, 1997.

[4] S. Kato, H. Endoh, Y. Masuhiro et al., "Activation of the estrogen receptor through phosphorylation by mitogen-activated protein kinase," Science, vol. 270, no. 5241, pp. 1491-1494, 1995.

[5] R. Lupu, M. Cardillo, C. Cho et al., "The significance of heregulin in breast cancer tumor progression and drug resistance," Breast Cancer Research and Treatment, vol. 38, no. 1, pp. 57-66, 1996.

[6] K. Brown, "Breast cancer chemoprevention: risk-benefit effects of the antioestrogen tamoxifen," Expert Opinion on Drug Safety, vol. 1, no. 3, pp. 253-267, 2002.

[7] L. L. Smith, K. Brown, P. Carthew et al., "Chemoprevention of breast cancer by tamoxifen: risks and opportunities," Critical Reviews in Toxicology, vol. 30, no. 5, pp. 571-594, 2000.

[8] H. Liu, Y. Liu, Z. Wang, and P. He, "Facile synthesis of monodisperse, size-tunable $\mathrm{SnS}$ nanoparticles potentially for solar cell energy conversion," Nanotechnology, vol. 21, no. 10, Article ID 105707, 2010.

[9] K. S. Shin, J.-Y. Choi, C. S. Park, H. J. Jang, and K. Kim, “Facile synthesis and catalytic application of silver-deposited magnetic nanoparticles," Catalysis Letters, vol. 133, no. 1-2, pp. 1-7, 2009.

[10] L. Zhou, X. He, D. He, K. Wang, and D. Qin, "Biosensing technologies for Mycobacterium tuberculosis detection: status and new developments," Clinical and Developmental Immunology, vol. 2011, Article ID 193963, 8 pages, 2011.

[11] P. S. S. Kumar, R. Sivakumar, S. Anandan, J. Madhavan, P. Maruthamuthu, and M. Ashokkumar, "Photocatalytic degradation of Acid Red 88 using $\mathrm{Au}-\mathrm{TiO}_{2}$ nanoparticles in aqueous solutions," Water Research, vol. 42, no. 19, pp. 4878-4884, 2008.

[12] R. Bhattacharya and P. Mukherjee, "Biological properties of "naked" metal nanoparticles," Advanced Drug Delivery Reviews, vol. 60, no. 11, pp. 1289-1306, 2008.

[13] S. Gurunathan, K. Kalishwaralal, R. Vaidyanathan et al., "Biosynthesis, purification and characterization of silver nanoparticles using Escherichia coli," Colloids and Surfaces B, vol. 74, no. 1, pp. 328-335, 2009.

[14] K. Kalishwaralal, V. Deepak, S. R. K. Pandian et al., "Biosynthesis of silver and gold nanoparticles using Brevibacterium casei," Colloids and Surfaces B, vol. 77, no. 2, pp. 257-262, 2010.

[15] M. I. Sriram, S. B. M. Kanth, K. Kalishwaralal, and S. Gurunathan, "Antitumor activity of silver nanoparticles in Dalton's lymphoma ascites tumor model," International Journal of Nanomedicine, vol. 5, no. 1, pp. 753-762, 2010.

[16] M. A. Malik, P. O’Brien, and N. Revaprasadu, "A simple route to the synthesis of core/shell nanoparticles of chalcogenides," Chemistry of Materials, vol. 14, no. 5, pp. 2004-2010, 2002. 
[17] K. N. Thakkar, S. S. Mhatre, and R. Y. Parikh, "Biological synthesis of metallic nanoparticles," Nanomedicinee, vol. 6, no. 2, pp. 257-262, 2010.

[18] R. Y. Parikh, S. Singh, B. L. V. Prasad, M. S. Patole, M. Sastry, and Y. S. Schouche, "Extracellular synthesis of crystalline silver nanoparticles and molecular evidence of silver resistance from Morganella sp.: towards understanding biochemical synthesis mechanism," ChemBioChem, vol. 9, no. 9, pp. 1415-1422, 2008.

[19] N. Pugazhenthiran, S. Anandan, G. Kathiravan, N. K. U. Prakash, S. Crawford, and M. Ashokkumar, "Microbial synthesis of silver nanoparticles by Bacillus sp.," Journal of Nanoparticle Research, vol. 11, no. 7, pp. 1811-1815, 2009.

[20] K. Kalimuthu, S. Vijayakumar, and R. Senthilkumar, "Antimicrobial activity of the biodiesel plant, Jatropha curcas L.", International Journal of Pharma and Bio Sciences, vol. 1, no. 3, article 29, 2010.

[21] I. Sondi and B. Salopek-Sondi, "Silver nanoparticles as antimicrobial agent: a case study on E. coli as a model for Gramnegative bacteria," Journal of Colloid and Interface Science, vol. 275, no. 1, pp. 177-182, 2004.

[22] J. R. Morones, J. L. Elechiguerra, A. Camacho et al., "The bactericidal effect of silver nanoparticles," Nanotechnology, vol. 16, no. 10, pp. 2346-2353, 2005.

[23] S. K. Gogoi, P. Gopinath, A. Paul, A. Ramesh, S. S. Ghosh, and A. Chattopadhyay, "Green fluorescent protein-expressing Escherichia coli as a model system for investigating the antimicrobial activities of silver nanoparticles," Langmuir, vol. 22, no. 22, pp. 9322-9328, 2006.

[24] P. Sanpui, A. Murugadoss, P. V. D. Prasad, S. S. Ghosh, and A. Chattopadhyay, "The antibacterial properties of a novel chitosan-Ag-nanoparticle composite," International Journal of Food Microbiology, vol. 124, no. 2, pp. 142-146, 2008.

[25] I. Banerjee, R. C. Pangule, and R. S. Kane, "Antifouling coatings: recent developments in the design of surfaces that prevent fouling by proteins, bacteria, and marine organisms," Advanced Materials, vol. 23, no. 6, pp. 690-718, 2011.

[26] P. Gopinath, S. K. Gogoi, A. Chattopadhyay, and S. S. Ghosh, "Implications of silver nanoparticle induced cell apoptosis for in vitro gene therapy," Nanotechnology, vol. 19, no. 7, Article ID 075104, 2008.

[27] P. V. A. Rani, G. L. K. Mun, M. P. Hande, and S. Valiyaveettil, "Cytotoxicity and genotoxicity of silver nanoparticles in human cells," ACS Nano, vol. 3, no. 2, pp. 279-290, 2009.

[28] S. Gurunathan, K.-J. Lee, K. Kalishwaralal, S. Sheikpranbabu, R. Vaidyanathan, and S. H. Eom, "Antiangiogenic properties of silver nanoparticles," Biomaterials, vol.30, no. 31, pp. 6341-6350, 2009.

[29] K. Kalishwaralal, E. Banumathi, S. R. K. Pandian et al., "Silver nanoparticles inhibit VEGF induced cell proliferation and migration in bovine retinal endothelial cells," Colloids and Surfaces B, vol. 73, no. 1, pp. 51-57, 2009.

[30] M. A. Franco-Molina, E. Mendoza-Gamboa, C. A. Sierra-Rivera et al., "Antitumor activity of colloidal silver on MCF-7 human breast cancer cells," Journal of Experimental and Clinical Cancer Research, vol. 29, no. 1, article 148, 2010.

[31] P. Sanpui, A. Chattopadhyay, and S. S. Ghosh, "Induction of apoptosis in cancer cells at low silver nanoparticle concentrations using chitosan nanocarrier," ACS Applied Materials and Interfaces, vol. 3, no. 2, pp. 218-228, 2011.

[32] Y. H. Hsin, C. F. Chen, S. Huang, T. S. Shih, P. S. Lai, and P. J. Chueh, "The apoptotic effect of nanosilver is mediated by a ROS- and JNK-dependent mechanism involving the mitochondrial pathway in NIH3T3 cells," Toxicology Letters, vol. 179, no. 3, pp. 130-139, 2008.

[33] S. M. Hussain, K. L. Hess, J. M. Gearhart, K. T. Geiss, and J. J. Schlager, "In vitro toxicity of nanoparticles in BRL 3A rat liver cells," Toxicology in Vitro, vol. 19, no. 7, pp. 975-983, 2005.

[34] S. Kim, J. E. Choi, J. Choi et al., "Oxidative stress-dependent toxicity of silver nanoparticles in human hepatoma cells," Toxicology in Vitro, vol. 23, no. 6, pp. 1076-1084, 2009.

[35] J. L. Martindale and N. J. Holbrook, "Cellular response to oxidative stress: signaling for suicide and survival," Journal of Cellular Physiology, vol. 192, no. 1, pp. 1-15, 2002.

[36] J. Sastre, F. V. Pallardó, J. G. de la Assunción, and J. Vińa, "Mitochondria, oxidative stress and aging," Free Radical Research, vol. 32, no. 3, pp. 189-198, 2000.

[37] C. Carlson, S. M. Hussein, A. M. Schrand et al., "Unique cellular interaction of silver nanoparticles: size-dependent generation of reactive oxygen species," Journal of Physical Chemistry B, vol. 112, no. 43, pp. 13608-13619, 2008.

[38] R. Foldbjerg, P. Olesen, M. Hougaard, D. A. Dang, H. J. Hoffmann, and H. Autrup, "PVP-coated silver nanoparticles and silver ions induce reactive oxygen species, apoptosis and necrosis in THP-1 monocytes," Toxicology Letters, vol. 190, no. 2, pp. 156-162, 2009.

[39] E.-J. Park, J. Yi, Y. Kim, K. Choi, and K. Park, "Silver nanoparticles induce cytotoxicity by a Trojan-horse type mechanism," Toxicology in Vitro, vol. 24, no. 3, pp. 872-878, 2010.

[40] Z. Shavandi, T. Ghazanfari, and K. N. Moghaddam, "In vitro toxicity of silver nanoparticles on murine peritoneal macrophages," Immunopharmacology and Immunotoxicology, vol. 33, no. 1, pp. 135-140, 2011.

[41] L. Braydich-Stolle, S. Hussain, J. J. Schlager, and M.-C. Hofmann, "In vitro cytotoxicity of nanoparticles in mammalian germ-line stem cells," Toxicological Sciences, vol. 88, no. 2, pp. 412-419, 2005.

[42] R. P. Nishanth, R. G. Jyotsna, J. J. Schlager, S. M. Hussain, and P. Reddanna, "Inflammatory responses of RAW 264.7 macrophages upon exposure to nanoparticles: role of ROS-NFKB signaling pathway," Nanotoxicology, vol. 5, no. 4, pp. 502-516, 2011.

[43] M. J. Piao, K. A. Kang, I. K. Lee et al., "Silver nanoparticles induce oxidative cell damage in human liver cells through inhibition of reduced glutathione and induction of mitochondriainvolved apoptosis," Toxicology Letters, vol. 201, no. 1, pp. 92100, 2011.

[44] P. Ahmad, M. Sarwat, and S. Sharma, "Reactive oxygen species, antioxidants and signaling in plants," Journal of Plant Biology, vol. 51, no. 3, pp. 167-173, 2008.

[45] G. M. Cohen, "Caspases: the executioners of apoptosis," Biochemical Journal, vol. 326, no. 1, pp. 1-16, 1997.

[46] A. H. Wyllie, "Glucocorticoid-induced thymocyte apoptosis is associated with endogenous endonuclease activation," Nature, vol. 284, no. 5756, pp. 555-556, 1980.

[47] S. Arora, J. Jain, J. M. Rajwade, and K. M. Paknikar, "Cellular responses induced by silver nanoparticles: in vitro studies," Toxicology Letters, vol. 179, no. 2, pp. 93-100, 2008.

[48] J. S. Kim, E. Kuk, K. N. Yu et al., "Antimicrobial effects of silver nanoparticles," Nanomedicine, vol. 3, no. 1, pp. 95-101, 2007.

[49] K. Kalishwaralal, V. Deepak, S. Ramkumarpandian, H. Nellaiah, and G. Sangiliyandi, "Extracellular biosynthesis of silver nanoparticles by the culture supernatant of Bacillus licheniformis," Materials Letters, vol. 62, no. 29, pp. 4411-4413, 2008. 
[50] H.-Y. Shim, J.-H. Park, H.-D. Paik, S.-Y. Nah, D. S. H. L. Kim, and Y. S. Han, "Acacetin-induced apoptosis of human breast cancer MCF-7 cells involves caspase cascade, mitochondriamediated death signaling and SAPK/JNK1/2-c-Jun activation," Molecules and Cells, vol. 24, no. 1, pp. 95-104, 2007.

[51] A. D. Edelstein and R. C. Cammarata, Nanomaterials Synthesis, Properties and Applications, Taylor \& Francis, Boca Raton, Fla, USA, 1996.

[52] T. Klaus-Joerger, R. Joerger, E. Olsson, and C.-G. Granqvist, "Bacteria as workers in the living factory: metal-accumulating bacteria and their potential for materials science," Trends in Biotechnology, vol. 19, no. 1, pp. 15-20, 2001.

[53] M. Sastry, K. S. Mayya, and K. Bandyopadhyay, "pH Dependent changes in the optical properties of carboxylic acid derivatized silver colloidal particles," Colloids and Surfaces A, vol. 127, no. 1-3, pp. 221-228, 1997.

[54] M. Sastry, V. Patil, and S. R. Sainkar, "Electrostatically controlled diffusion of carboxylic acid derivatized silver colloidal particles in thermally evaporated fatty amine films," Journal of Physical Chemistry B, vol. 102, no. 8, pp. 1404-1410, 1998.

[55] A. R. Shahverdi, S. Minaeian, H. R. Shahverdi, H. Jamalifar, and A.-A. Nohi, "Rapid synthesis of silver nanoparticles using culture supernatants of Enterobacteria: a novel biological approach," Process Biochemistry, vol. 42, no. 5, pp. 919-923, 2007.

[56] K. Kalimuthu, R. S. Babu, D. Venkataraman, M. Bilal, and S. Gurunathan, "Biosynthesis of silver nanocrystals by Bacillus licheniformis," Colloids and Surfaces B, vol. 65, no. 1, pp. 150-153, 2008.

[57] R. E. L. Shanshoury, S. E. Elsilk, and M. E. Ebeid, "Extracellular biosynthesis of silver nanoparticle using Escherichia coli ATCC, 8739, Bacillus subtilis ATCC, 6633, and Streptococcus thermophilus ESh1 and their antimicrobial activity," ISRN Nanotechnology, vol. 2011, Article ID 385480, 7 pages, 2011.

[58] M. V. D. Z. Park, A. M. Neigh, J. P. Vermeulen et al., “The effect of particle size on the cytotoxicity, inflammation, developmental toxicity and genotoxicity of silver nanoparticles," Biomaterials, vol. 32, no. 36, pp. 9810-9817, 2011.

[59] X. L. Song, B. Li, K. Xu et al., "Cytotoxicity of water-soluble mPEG-SH-coated silver nanoparticles in HL-7702 cells," Cell Biology and Toxicology, vol. 28, no. 4, pp. 225-237, 2012.

[60] Y. S. Lee, D. W. Kim, Y. H. Lee et al., "Silver nanoparticles induce apoptosis and $\mathrm{G} 2 / \mathrm{M}$ arrest via $\mathrm{PKC} \zeta$-dependent signaling in A549 lung cells," Archives of Toxicology, vol. 85, no. 12, pp. 15291540, 2011.

[61] C. Zanette, M. Pelin, M. Crosera et al., "Silver nanoparticles exert a long-lasting antiproliferative effect on human keratinocyte HaCaT cell line," Toxicology in Vitro, vol. 25, no. 5, pp. 1053-1060, 2011.

[62] A. Nel, T. Xia, L. Mädler, and N. Li, "Toxic potential of materials at the nanolevel," Science, vol. 311, no. 5761, pp. 622-627, 2006.

[63] J. L. Martindale and N. J. Holbrook, "Cellular response to oxidative stress: signaling for suicide and survival," Journal of Cellular Physiology, vol. 192, no. 1, pp. 1-15, 2002.

[64] J. Sastre, F. V. Pallardö, and J. Viña, "Mitochondrial oxidative stress plays a key role in aging and apoptosis," IUBMB Life, vol. 49, no. 5, pp. 427-435, 2000.

[65] C. Gianinazzi, D. Grandgirard, H. Imboden et al., "Caspase-3 mediates hippocampal apoptosis in pneumococcal meningitis," Acta Neuropathologica, vol. 105, no. 5, pp. 499-507, 2003.

[66] T. Matsura, M. Kai, Y. Fujii, H. Ito, and K. Yamada, "Hydrogen peroxide-induced apoptosis in HL-60 cells requires caspase-3 activation," Free Radical Research, vol. 30, no. 1, pp. 73-83, 1999.
[67] T. S. Zheng, S. F. Schlosser, T. Dao et al., "Caspase-3 controls both cytoplasmic and nuclear events associated with Fas-mediated apoptosis in vivo," Proceedings of the National Academy of Sciences of the United States of America, vol. 95, no. 23, pp. 13618-13623, 1998.

[68] R. Alvarez-Gonzalez, H. Spring, M. Müller, and A. Bürkle, "Selective loss of poly(ADP-ribose) and the $85-\mathrm{kDa}$ fragment of poly(ADP- ribose) polymerase in nucleoli during alkylationinduced apoptosis of HeLa cells," Journal of Biological Chemistry, vol. 274, no. 45, pp. 32122-32126, 1999.

[69] R. Hu, K.-T. Yong, I. Roy, H. Ding, S. He, and P. N. Prasad, "Metallic nanostructures as localized plasmon resonance enhanced scattering probes for multiplex dark-field targeted imaging of cancer cells," Journal of Physical Chemistry C, vol. 113, no. 7, pp. 2676-2684, 2009.

[70] R. T. Allen, W. J. Hunter III, and D. K. Agrawal, "Morphological and biochemical characterization and analysis of apoptosis," Journal of Pharmacological and Toxicological Methods, vol. 37, no. 4, pp. 215-228, 1997.

[71] J. Wang, G. Zhou, C. Chen et al., "Acute toxicity and biodistribution of different sized titanium dioxide particles in mice after oral administration," Toxicology Letters, vol. 168, no. 2, pp. 176$185,2007$.

[72] P.-J. Lu, I.-C. Ho, and T.-C. Lee, "Induction of sister chromatid exchanges and micronuclei by titanium dioxide in Chinese hamster ovary-K1 cells," Mutation Research, vol. 414, no. 1-3, pp. 15-20, 1998.

[73] R. M. Mroz, R. P. F. Schins, H. Li et al., "Nanoparticledriven DNA damage mimics irradiation-related carcinogenesis pathways," European Respiratory Journal, vol. 31, no. 2, pp. 241251, 2008. 

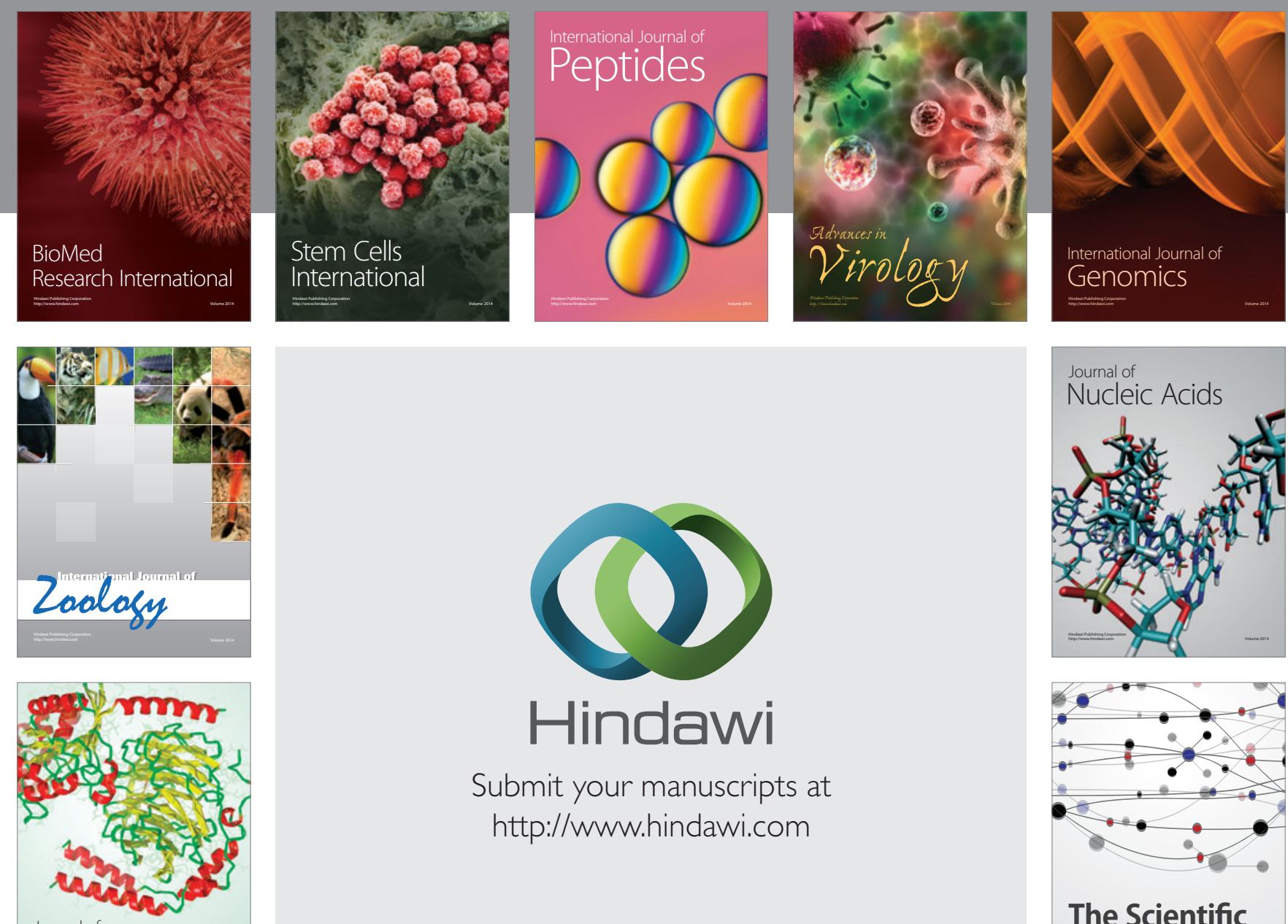

Submit your manuscripts at

http://www.hindawi.com

Journal of
Signal Transduction
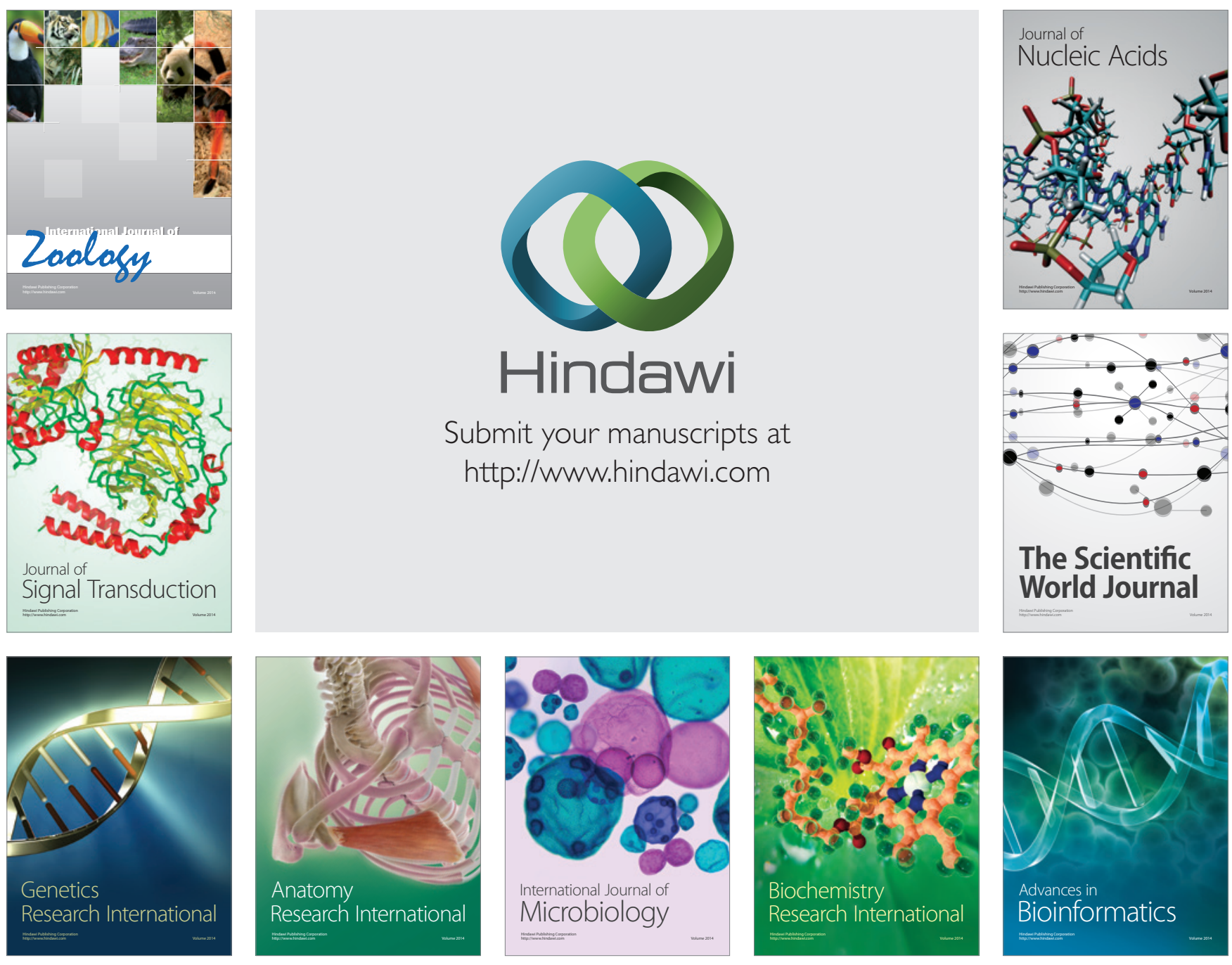

The Scientific World Journal
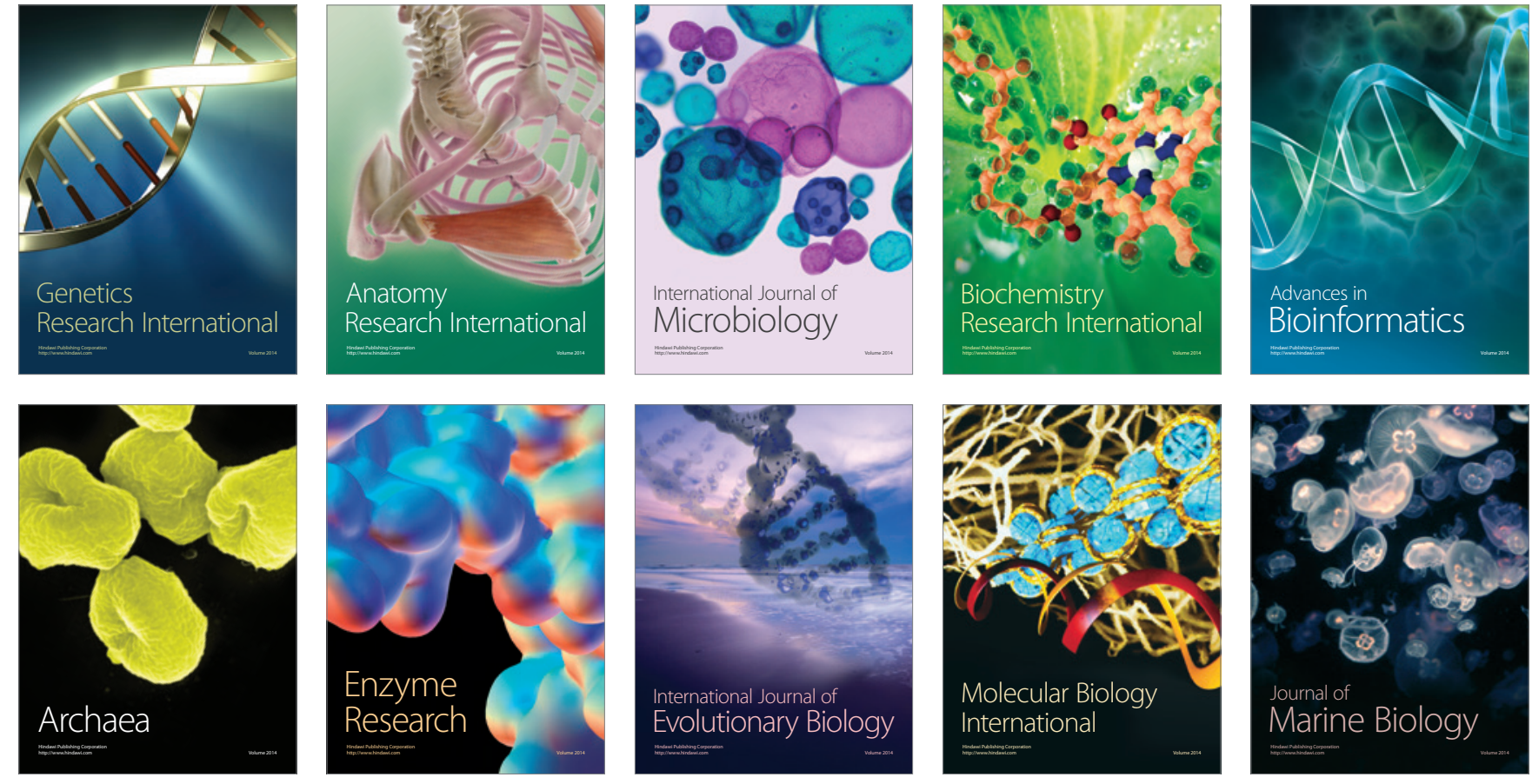